\title{
A Reading of Fragments 926(a) and 926(g) PMG within the Context of the New Music*
}

\author{
Vasiliki Kousoulini \\ National and Kapodistrian University of Athens, Faculty of Philology, School of Philosophy, \\ University Campus Zografou, Athens 15784, Greece; vasiakous@yahoo.gr
}

For citation: Kousoulini V. A Reading of Fragments 926(a) and 926(g) $P M G$ within the Context of the New Music. Philologia Classica 2021, 16 (1), 18-31. https://doi.org/10.21638/spbu20.2021.102

There has been much controversy regarding the date, the performative context, and the generic quality of fragment 926 PMG, which has been preserved on papyrus (P. Oxy. 9+ P. Oxy 2687) in a rhythmical treatise by an unknown author. The verse fragments on this papyrus were composed in iambic dactyls $(\cup-\cup-)$ and used as examples of the occurrence of syncope in various lyric meters. Fragments 926(a) and (g) PMG are from a composition performed by a maiden chorus which bear similarities to Alcman's partheneia and have affinities with archaic epic and lyric poetry. Supposedly, these fragments might have been fragments of partheneia composed in the time of the New Music. Nonetheless, they are not shaped according to the bulk of the aesthetic values and the compositional rules of the New Music. These fragments seem to belong to cultic songs created for maiden choruses, possibly, to honor Dionysus. The alternative is that they imitate such songs within a dramatic context. We may assume that these quasi-dithyrambic partheneia were composed to serve religious needs or at least imitated cultic songs. They looked backward to the archaic and early classical tradition of partheneia, and their existence is an indication that, in the days of the New Music, there was a poetic tradition upheld by "reactionary" poets.

Keywords: New Music, partheneia, late classical lyric.

\section{Introduction}

Late classical lyric poetry performed to the auloi or kithara is usually associated with the New Music. ${ }^{1}$ Nonetheless, there are clues that, during the same period, more traditional lyric genres were still composed and performed. Fragments 926(a) and 926(g) PMG come from a third-century A.D. papyrus (P. Oxy. 9+ P. Oxy 2687) that contains an excerpt of a rhythmical treatise. These fragments are quoted along with five other fragments that betray characteristics of the dithyramb. ${ }^{2}$ They refer to dance movements performed dur-

* This research is co-financed by Greece and the European Union (European Social Fund- ESF) through the Operational Programme "Human Resources Development, Education and Lifelong Learning" in the context of the project "Reinforcement of Postdoctoral Researchers - 2nd Cycle" (MIS-5033021), implemented by the State Scholarships Foundation (IKY).

${ }^{1}$ See LeVen 2010, 35. For the importance of the performances on kithara in regard to shaping the New Music see Power 2010.

2 This is true especially for fragments 926(b), (c), (d), and (f) PMG. Fragment 926(e) is rather short and does not provide enough information regarding its performative context. Page believes that all of them are dithyrambic (see Page 1941). According to LeVen $(2014,61)$, they belong to dithyrambic contexts.

(C) St. Petersburg State University, 2021 


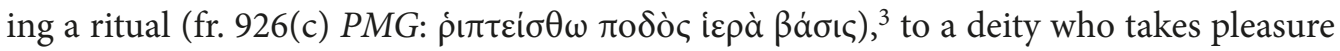

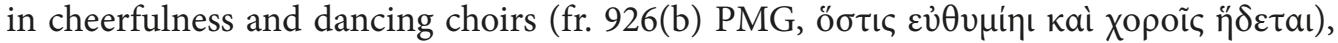
to something that is a gift to the Graces and a rest for mortals from toil (fr. 926(e) PMG:

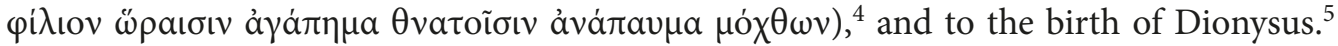
The rhythmical treatise provides no information to suggest that all these fragments come from the same song. Since most of them refer to Dionysus, have traits of the Doric dialect, ${ }^{6}$ and are examples of the same metrical phenomenon, they may even come from the same song or, at least, from songs that belonged to the same lyric genre and were composed around the same date. Most scholars assume that fr. 926(a) and (b) are from the same piece. ${ }^{7}$ Calviè suggests that fr. $926(\mathrm{c}),(\mathrm{d})$, and (e) belong to the same song. ${ }^{8}$ Fragments 926(a), (b), (c), (g) seem to come from choral songs.

Unlike the rest of the fragments, 926(a) and (g) provide information regarding the gender of the performers; the reader learns that these are maiden choruses. This is a rather uncommon trait, provided that the fragments belong to a dithyrambic context. Dithyrambs were, normally, performed by men or boys; those performed by women were a rare phenomenon ${ }^{9}$ and are encountered mainly in drama. ${ }^{10}$ On the other hand, 926(a) and (g) have similarities with archaic partheneia and other traditional lyric and dramatic genres. Below it is claimed that, although composed in the time of the New Music, these fragments are not New Musical ${ }^{11}$ songs and might be generically affiliated with partheneia.

\section{The Fragments and their Date}

A) 926(a) $P M G$ (P. Oxy. 9+ P. Oxy. 2687, col. i-ii)

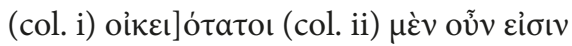

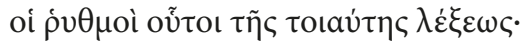

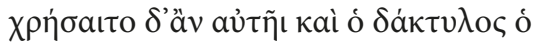

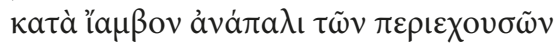

${ }^{3}$ I follow the text and the numbering of Campbell.

4 The wording resembles that of Crates' of Thebes hymn to Euteleia (fr. $361 \mathrm{SH}$ : Xaĩ $\rho \varepsilon, \theta \varepsilon a ̀$ $\delta \varepsilon \sigma \pi o t v \alpha$, $\sigma o \phi \tilde{\omega} v \dot{\alpha} v \delta \rho \tilde{\omega} v \alpha \dot{\alpha} \alpha \dot{\pi} \pi \eta \alpha)$. It is not impossible that the song to which it belonged had a hymnic quality. It certainly belonged to praise contexts. The Horai were also mentioned in one of Pindar's dithyrambs (fr. 75 SM). They seem to have an association with Dionysus, and they could often appear in his train (see on this Neer 2014, 570-573, with more bibliography).

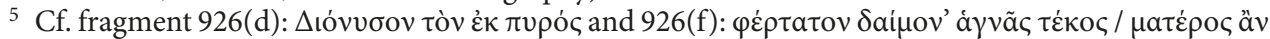

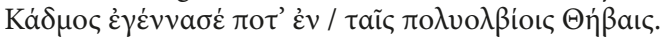

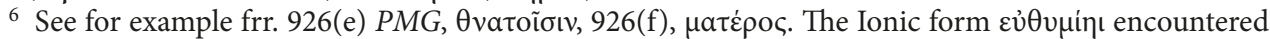
in fragment 926(b) was used by Wilamowitz as evidence that this fragment could not belong to a dithyramb. See Wilamowitz 1898, 699, n. 2.

7 See Rossi 1988, 24; Gentili 1995, 18; Horden 2002, 20, n. 55; Calviè 2014, 34.

8 See Calviè 2014, 34 .

9 The surviving dithyrambs do not allow us to draw certain conclusions. Fr. 871 PMG could have been a dithyramb sung by women. See Calame 1997, 79-80. Women, possibly, performed a dithyramb preserved on a lyric papyrus PSI 1181 attributed to Bacchylides (fr. 60-61 dubia). It is likely that Bacchyl. Dith. 20 and Telesilla's fr. $748 P M G$ were dithyrambs performed by female choruses. See D’Alessio 2013, 125-126.

10 The songs of some of Euripides' female choruses have been considered dithyrambs or, at least, dithyrambic (e. g., the parodos of the Bacchae). See on this Seaford 1996, 29, 156-157; Csapo 1999-2000, 408-409, with more examples and bibliography.

11 I prefer the term "New Musical" to the narrower term "New Dithyrambic". This term, to the best of my knowledge, was first coined by Csapo (2009, 95, n. 1, with more bibliography). 


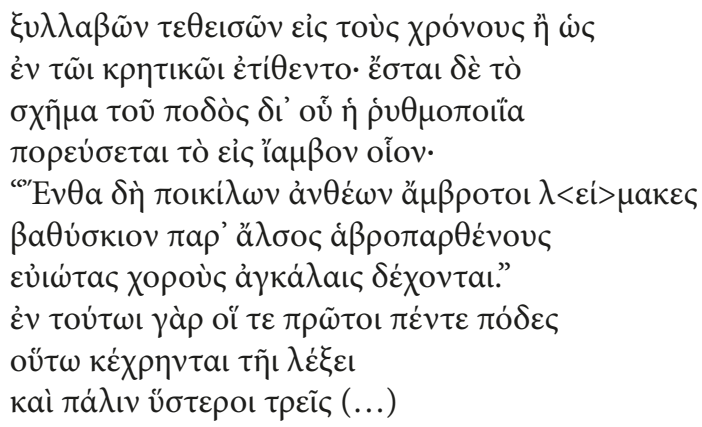

"These rhythms, then, are the most suitable for this sort of word-grouping. But the iambic type of dactyl $(\cup-\cup-)$ may also use it (in the form $(L \cup-)$, the outside syllables being assigned to the feet in an order the reverse of that in which they are assigned in the cretic $(-\cup\lrcorner)$. The pattern of the foot in which the rhythmical composition proceeds will end in an iambus $(L \cup-)$, e.g.: 'There immortal meadows of many-coloured flowers welcome in their embrace by the deep-shadowed grove the bacchant choirs of tender maidens.' In this passage the first five feet use the word-group this way, as do three later feet also (...)" (Transl. Campbell 1993).

B) 926(g) PMG (P. Oxy. 9+ P. Oxy. 2687, col. iii)

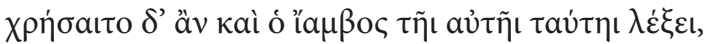

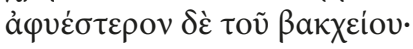

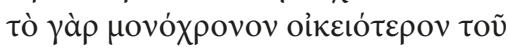

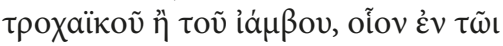

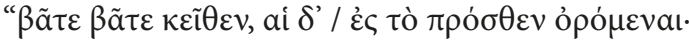

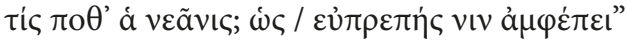

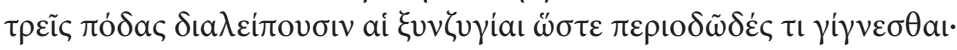

"The iambus also may use this same word-group ( $L \cup-$ ), but less naturally than does the bacchius $(-\cup \cup-)$, for the single element ( $\left.L_{\text {or }}\right\lrcorner$ ) is more at home in the trochaic part (of the bacchius) than in the iambus; e.g., in: 'Come from there, come, and you other girls, come rushing, to the front whoever is that young girl? What handsome ..., surrounds her!' - the couplings occur every third foot so as to produce a kind of periodic effect." (Transl. Campbell 1993).

The papyrus is thought to contain excerpts of Aristoxenus' treatise Elements of Rhythm. ${ }^{12}$ The cited verses in iambic dactyls exemplify the occurrence of syncope in various lyric meters. ${ }^{13}$ With syncope, under certain conditions, the long syllable can be lengthened to the value of three or more time-units, as the author attests.

Recently, the attribution of the papyrus to Aristoxenus has been challenged. Mathiesen remarks that this excerpt provides one of the specific topics regarded as missing from other fragments of the Elements of Rhythm, such as the specific comments on rhythmic compo-

12 See on this Page 1962, 494.

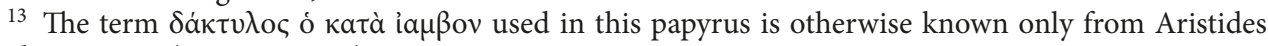
Quintilianus 1.17 (=38.5-6 W-I). 
sition. Although he does not doubt that this excerpt was part of the Elements of Rhythm, he observes the similarities of language and approach to Aristides Quintilianus' treatise On Music. ${ }^{14}$ However, Calviè suggests that the views here expressed should not be attributed to one person but rather to a school. ${ }^{15}$ Moreover, based on papyrological, paleographical, linguistic, stylistic and thematic criteria, he argues that the papyrus should be attributed to a representative of a school rival to that of Aristoxenus, and probably active already in the fifth century BC. ${ }^{16}$ Marchetti emphasizes that, although the papyrus shares some technical terminology with Aristoxenus' Elements of Rhythm, its approach to rhythm is very different. According to Marchetti, the text is practical in orientation, as its author readily provides examples of many of his points. The papyrus also lacks a number of key Aristoxenian terms. ${ }^{17}$

Uncertainty reigns as to the date of the fragments. Wilamowitz suggested the late fourth century BC. ${ }^{18}$ Some modern scholars argue for the mid-third century BC. ${ }^{19}$ However, Marchetti pleads for a much earlier date, "the time of the New Music", i. e. the late fifth century. ${ }^{20}$ Considering that the authorship of Aristoxenus is more than dubious, we may seek for the clues in the rhythmical analysis of the fragments. If the information from the author was lacking, anyone examining these fragments would probably have a different interpretation of their meter, ${ }^{21}$ namely, that the metrical sequence of fragment 926(a) is $-5 \mathrm{cr} / / 3 \mathrm{ia} / / 2 \mathrm{cr}$ ith and the metrical sequence of fragment $926(\mathrm{~g})$ is -4 lec. Nothing but the evidence from the treatise enables us to learn that the first long in the cretic sequences $-\cup-$ was three time-units long. This could only be clear to someone who heard these poems performed. Therefore, the length of time between the composition of the poems and the treatise must have been short enough to allow for the transmission of the music. The fragments might have been performed during the author's lifetime. Thus, it is highly improbable that they belong to archaic lyric poetry.2 The triseme longs found in these fragments are also significant in terms of their dating. The lengthening of a syllable may require it to be dragged over different notes. This practice is called melism and is an acknowledged feature of the New Music. ${ }^{23}$ The use of melism is an indication that these fragments belong to the timeframe of the New Music.

Experts in ancient music have noticed that the exact metrical practice of these fragments is unparalleled in classical drama. The tragedians did not use a triseme syllable for the first foot of an iambic dipody. ${ }^{24}$ Nonetheless, they used triseme syllables in syncopated

14 See Mathiesen 1999, 343-344. Koster also observed the similarities with Aristides Quntilianus (see Koster 1972, 50-55).

15 See Calviè 2014, 35.

16 See Calviè 2014, 7-54, with more bibliography.

17 See Marchetti 2009, 237.

18 See Wilamowitz 1989. Cole 1988 and Rossi 1988 accept his arguments.

19 Reinach 1898, 389-414; Koster 1972, 47-56; Pearson 1990, 36-44, 77-86.

20 Marchetti 2009, 251.

${ }^{21}$ I owe this observation to the anonymous reader of Philologia Classica.

22 This could have been the case if the author had heard a reperformance of these songs that was extremely faithful to their original performance.

23 Aristophanes in the Frogs (lines 1314, 1348) parodies this New Musical feature where a line from Euripides' Electra has its first syllable repeated anywhere from five to seven times. We encounter this feature in many New Musical songs (e. g., in the Rainer papyrus of Euripides' Orestes or in P. Berol. 6870 which probably contains fragments of Timotheus' Mad Ajax). On melism as a characteristic of the New Music see Csapo 2004, 223; Irigoin 2006, 30-31; LeVen 2014, 73 n. 10, with further references.

24 See Marchetti 2009, 251, with more bibliography. Marchetti suggests that the tragedians used triseme longs in a sequence $\cup-\cup--\cup$, that is, the fourth syllable of the diiambus and not the first 
iambic and trochaic meters, and this can be surmised from the possibility of responsion between syncopated and non-syncopated forms. ${ }^{25}$ In fact, cases of responsion between iambs or trochees and cretics are too rare and uncertain for any decisive conclusion of this kind. We cannot be certain whether or not this use of the metrical practice in question ${ }^{26}$ excludes the possibility that the fragments belong to drama, at least to the late fifth-century drama.

\section{New Musical Songs?}

As we have seen, fr. 926(a) and (g) come from a treatise that was probably written during the fifth century BC. ${ }^{27}$ Their date renders them candidates for being New Musical songs. Nonetheless, calling a song New Musical creates more problems than it solves. New Music was not a specific category of poetic compositions with established generic rules. Rather, it is an umbrella term used to describe the various trends of Greek poetry during the fifth and early fourth centuries. ${ }^{28}$ These trends were a result of advances in musical practice that had an impact on instruments, design, and musical form which allowed (if not encouraged) the flexibility in melody. ${ }^{29}$ A certain piece can usually be attributed to the New Music because of the name of its author ${ }^{30}$ or, more problematically, because it includes the characteristic features for which the New Music pieces were notorious.

The existence of a "corpus" of New Musical songs is also disputable. ${ }^{31}$ Several later Euripidean odes have been considered examples of the above-mentioned trends. ${ }^{32}$ Very few fragments of cultic New Musical songs are preserved in mss. or papyri, ${ }^{33}$ and there is a handful of short quotations by ancient authors. ${ }^{34}$ The sources regarding private genres of the New Music are even more limited. As LeVen notes, "The bulk of data is related to the very public forms of late classical lyric, ... much less material is available about scolia, encomia, and epithalamia which were less civic and less religious kinds of songs" ${ }^{35}$ She also notes that the fragments quoted by the authors of technical treatises seem to have a

one of the cretic would be triseme, since classical poetry does not allow resolution of a long syllable before syncopation, so the syllable before the syncopation was always the one lengthened to triseme.

${ }_{25}$ Wilamowitz 1898, 698, 700-701.

26 See Reiter 1887, 1893; Denniston 1936, 121-144; Dale 1948, 73-75; West 1982, 103-104, 1990, 109-110. Some of the rare occurrences of syncopated iambic metra - mostly cretic - responding with full ones in tragedy might be the following: Aesch. Cho. 800-812; Eur. Andr. 140-146, El. 1185-1201, Hel. 174-186, Or. 965-976.

27 Marchetti 2009, 251; Calviè 2014, 7-54.

28 See on this Csapo 1999-2000, 401; D’Angour 2006, 267.

29 See Csapo 2004, 25; 2009, 108; 2012; D’Angour 2006, 264-288; Franklin 2013, 214-220.

30 If he is among those who are criticized in ancient sources, as for instance Melanippides of Melos, Cinesias of Athens, Timotheus of Miletus, Philoxenus of Cythera (and/or Leucas), Telestes of Selinous, Polyidus of Selembria, and the musicians Phrynis of Mytilene and Pronomus of Thebes. Most of these names appear in a passage from a comedy by Pherecrates (Cheiron fr. $155 \mathrm{~K}-\mathrm{A}$ ) which describes the innovations introduced in traditional music at the end of the fifth century BC.

${ }^{31}$ I regard that there was no corpus of New Musical texts in the sense that the composers of songs that were considered New Musical self-consciously composed them. When I refer to the New Musical "corpus", I mean the texts exhibiting some of the characteristics that ancient literary critics and contemporary scholars attribute to late classical lyric poetry.

32 On this see Csapo 1999-2000; 2003.

33 For evidence see LeVen 2014, 33-39.

${ }^{34}$ For a comprehensive catalog of the modern editions of these fragments see ibid. 2010, 35, n. 1.

35 Ibid. 39-40. 
more Dionysian tone and are less elaborate than the rest of the New Poems. ${ }^{36}$ The public forms of the New Music include pieces composed for regular festivals, such as dithyrambs and nomes. Informing on the authors considered to have composed the New Music, yet without mentioning the term itself, the Suda refers to the lyric songs and dithyrambs,

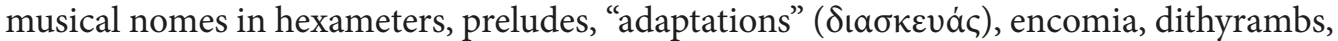

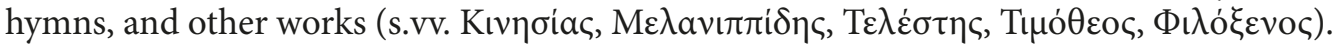
We should perhaps suppose that each New Musical genre had different "generic" traits.

No less difficult is to specify the characteristics of the New Musical songs, though many scholars, both ancient and contemporary, have tried to define them. The lists of distinguishing marks predominantly come from the criticisms of philosophers and adversaries of democracy. ${ }^{37}$ The poets who composed those pieces were not obliged to selfconsciously align themselves with strict compositional rules. Nevertheless, some of the characteristics noted by ancient scholarship on the matter can be encountered in a large part of the surviving poetry of the period. The many-notedness ( $\pi \mathrm{o} \lambda \nu \varphi \omega v i \alpha)$ and com-

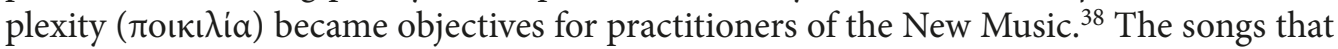
have been considered New Musical seem to have rather particular stylistic features in language, ${ }^{39}$ meter, and sound effects. ${ }^{40}$ The New Music texts are usually dense with verbal sound effects, puns, far-fetched metaphors, elaborate periphrases, riddles, and bold compound epithets. ${ }^{41}$ Their syntax is accumulative and avoids hypotaxis. ${ }^{42}$ They seem to mix traditional and innovative styles. ${ }^{43}$ To their features belong intertextuality ${ }^{44}$ and

36 Ibid. 61, n. 92.

37 See Csapo 1999-2000, 404-405; Martin 2003, 153-154. Philosophers considered the New Music to be a product of democratic mob-culture and believed that it appealed to the vulgar tastes of the masses: Pl. Leg. 700 a-701b; Arist. Pol. 1341b; [Plut.] De Mus. 1135e. For the political overtones of the description of the practitioners of the New Music in Pherecrates' Cheiron (fr. 155 K-A) see Franklin 2013.

38 See Csapo 2004, 220; Franklin 2013, 216; Budelmann 2014, 191. For many-notedness as a characteristic of the New Music see Pherecrates Cheiron (fr. 155 K-A); [Plut.] De Mus. 1141d. For $\pi$ oı ılía see [Plut.] De Mus. 1142b-c.

39 Language was a distinguishing feature of the New Dithyramb. On this see e. g., Schönewolf 1938, 25, 41; Dover 1997, 47; Hordern 2002, 40; Csapo 2004, 223-224; Ford 2013, 313; Budelmann 2014, $191-192$.

40 For the repetitions of sounds as characteristic of the New Music see examples in Csapo 2004, 223224. See also Leven 2014, 187. Csapo notes that the repetition of words or syllables was typical of archaic hymns and cultic songs, especially those of Dionysos, and it was revived by the New Dithyramb poets.

41 See Ford 2013, 314; Budelmann 2014, 191. The existence of compound epithets is not evidence per se that a fragment belongs to the New Music, since these are not infrequent either in archaic choral lyric or in classical tragedy.

42 See Csapo 2004, 225-226; 2009, 108; Ford 2013, 315; Budelmann 2014, 191. For the simplicity of syntax being characteristic of New Musical texts see also the examples (mainly from Timotheus' Persians) in LeVen 2014, 151-152; 184.

43 On this point, however, caution is necessary. As Weiss $(2018,10-11,23-58)$ underlines, New Music should not be viewed within a cultural vacuum, as a movement wholly divorced from previous musical trends. There has been a long tradition of innovation in archaic and classical lyric and more traditional aspects of New Musical compositions. LeVen (2014, 103-108, 244-245) also notes that the New Poets relied on traditional diction, images, and themes. Csapo (2004, 230-247) believes that there was not such a thing as a timeless musical tradition opposed to the New Music. This unchanging, universal tradition was an invention of critics. New Poets often tried to recreate or reinvent the cultic and Dionysiac character of dithyrambic and cultic music. The style and imagery of many New Musical verses depend on traditional cultic and Dionysiac forms (on this Csapo 2003, 70).

44 For intertextuality as a trait of New Musical texts (especially of Timotheus' Persians) see LeVen 2014, 69-113, 184-185. More specifically, later fifth-century poets had to become indebted to the earlier lyric tradition to mark their innovations, as Fearn has suggested (see Fearn 2015, 2). Acosta-Hughes rightly considers the poets of the New Music pre-Hellenistic poets. 
genre-blending. ${ }^{45}$ The New Music poets tried to influence the emotional life of the audience. ${ }^{46}$ They created synesthetic images, full of sensuality and vividness. ${ }^{47}$ The imagery was feminine, orientalizing or bacchic. ${ }^{48}$ The poets were preoccupated with Dionysus, displayed interest in everything exotic, emphasized less familiar aspects of mythology and erudition. ${ }^{49}$

The fragments under analysis do exhibit certain morphological features of the New Musical songs. Wilamowitz was the first to stress that the metric variation encountered in these fragments is an indication of their later date. ${ }^{50}$ Melism, a recognized feature of the New

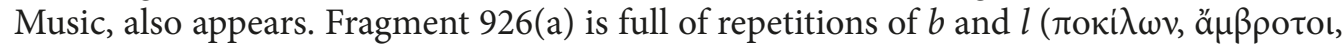

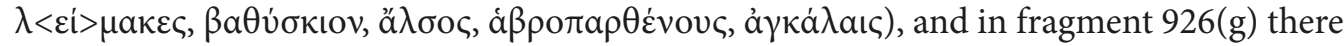
is a repletion of the word $\beta \tilde{\alpha} \tau \varepsilon$ for emphasis and probably of $r$ sounds ( $\pi \rho o ́ \sigma \theta \varepsilon v$, ópó $\mu \varepsilon v a$, $\varepsilon \dot{\pi} \pi \dot{\varepsilon} \pi \eta \varsigma)$. As concerns their syntax, they both lack hypotaxis. Nonetheless, these are not decisive clues to suggest that the fragments at hand belong to the New Music, since most of these features do appear in archaic poetry. Intentional sound effects are not easily detected, and it is often unclear whether their use was deliberate. ${ }^{51}$ Sound effects are very common in tragedy, especially in Aeschylus. ${ }^{52}$ The anadiplosis in addressing is not a peculiarity of the New Musical songs. It also appears in archaic lyric and classical drama. ${ }^{53}$ Abundant use of subordinate clauses is typical for these genres as well. ${ }^{54}$

The language of the fragments displays elements of the Doric dialect $(\pi \circ \theta, \dot{\alpha}) .{ }^{55}$ It has affinities with archaic epic and lyric diction, ${ }^{56}$ and there are rare words, such as

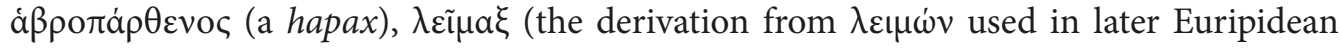

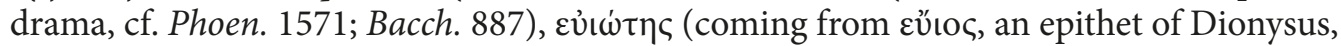
this word is found in the fragments of Moschion ${ }^{57}$ ), the poetic verb á $\mu \varphi \dot{\varepsilon} \pi \omega$ in the place of the more common á $\mu \varphi \iota \varepsilon \dot{\varepsilon} \pi \omega{ }^{58}$ The similarities with $5^{\text {th }}$ and $4^{\text {th }}$ century tragedy make it

45 The idea of past generic purity is a construct, seen most clearly in Pl. Leg. 700a-701d. Genre-blending was not alien to archaic lyric (cf. e. g., Pindar's description of the origins of lamentation in fr. 128 SM and Ford 2002, 15-16), but we encounter it more often in late classical lyric poetry. There were dithyrambs composed about Hymenaios, a figure who was a marker of epithalamia (such as Philoxenus' 825 and Telestes' 868 PMG). Artemis was described in terms more suited to Dionysos in a dithyramb composed by Timotheus (778b). Persephone was the subject of a dithyramb by Melanippides (759).

46 Csapo 2004, 217, 226; 2009, 95, 108; 2011, 77; LeVen 2014, 187, 168, 226; Budelmann 2014, 192.

47 LeVen 2014, 170-178.

48 Csapo 2011, 130. Csapo notes that most of the personae chosen for the choruses and solos are female. He notes that almost every Euripidean play after Heracles has a female chorus.

49 Cf. Csapo 2004, 215; Franklin 2013, 217, 231-232; Power 2013, 239; LeVen 2014, 64. On erudition as a characteristic of the New Music: Pl. Leg. 700e.

50 Wilamowitz 1898, 698, 700-701. Wilamowitz argues that these fragments cannot belong to the corpus of archaic lyric poetry. See also Marchetti 2009, 251.

51 See Stanford 1967, 99-100.

52 See Nooter 2017, 70-123.

53 E. g., in Carm. Pop. fr. 2 Page and Archil. fr. 128 West. According to Plutarch's Aetia Romana et Graeca 299B, anadiplosis in addressing appears after an appeal to Dionysus in a hymn performed at a festival

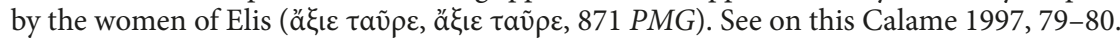

54 See Mülke 2002 on fr. 36 W.

55 This is true especially for fr. $926(\mathrm{~g})(\pi \mathrm{o} \theta, \dot{\alpha})$.

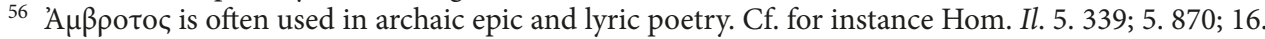

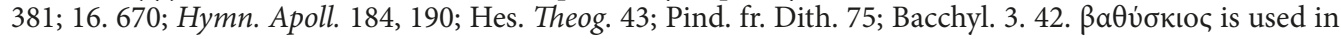
the Homeric hymn to Hermes 229.

${ }^{57} \mathrm{Fr} .7$ p. $633 \mathrm{~N}$. It is used to designate the vines in a fragment describing the human condition before civilization.

58 See Soph. Ant. 1177, El. 651; Eur. Phoen. 149, 340, Hyps. 164, IT. 1249. 
possible that the fragments belong to the same context. Nonetheless, there are differences between them and the canonical New Musical songs. They do not contain any of the puns, metaphors, or periphrases encountered in the New Dithyramb. Written, most probably, at the same time as the canonical New Musical songs, they seem more traditional. ${ }^{59}$

\section{Partheneia?}

The genre of the above cited fragments is questionable. Their performative context is not entirely discernable and does not provide definite clues regarding their generic quality. The rest of the fragments preserved on the papyrus are dithyrambic, but we cannot know if all of them came from the same song. Fragment 926(a) seems to be composed for outdoor performance, perhaps in a meadow near a grove. The performers are likely to be

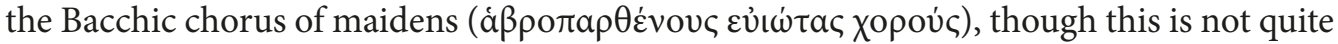
clear since the identity of the speaker remains unknown. The fragment was performed by a circle of bacchantes or created to represent this performance. ${ }^{60}$ There is little informa-

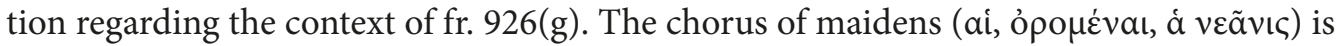

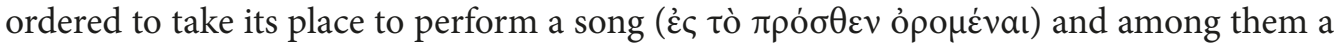
certain young woman seems to be more distinguished than her companions. It is unconceivable, whether the speaker describes a chorus or is its member. No intratextual clues definitely tie this fragment to a Dionysian performative context.

The Dionysian character of the fragments has not gone unnoticed, and the most authoritative hypothesis regarding their genre is that like the rest of the fragments preserved on the same papyrus they belonged to dithyrambs. ${ }^{61}$ Some suggest that they might be fragments of a satyr-play. ${ }^{62}$ It has also been assumed that fragment $926(\mathrm{~g})$ belongs to tragedy. ${ }^{63}$ LeVen notices that the fragments show traits "characteristically associated with the dithyrambic style," ${ }^{4}$ but seem to belong to less public or less showy forms of performance and have a prominent Dionysian tone.$^{65}$ She wonders whether they could be fragments of traditional cultic poems; still, no definite answer on this point is provided. ${ }^{66}$ Page suggests that fragment $926(\mathrm{~g})$, at least, seems to come from a partheneion and not from a dithyramb. ${ }^{67}$ Calame tends to agree with this, based on the content of the fragment. ${ }^{68}$

59 Cf. Hordern 2002, 20; Calvié 2014, 35.

60 The intratextual indications for the performance of a song can be misleading. Sometimes choruses seem to imitate other performances. Henrichs has coined the term choral projection to describe the tendency of tragic choruses to locate their own dancing in the past or the future, or refer to groups of dancers who are outside the concrete space of the orchestra and who dance in the realm of the dramatic imagination. See Henrichs 1994/95, 6; 1996, 49. On choral mimesis see also Nagy 1990, 42-44; 2013, 227-229.

${ }^{61}$ See Grenfell 1898, 14; Wilamowitz 1898; Blass 1899, 35; Pearson 1990, 79; LeVen 2014, 40; 61; Cole 1988; Rossi 1988; Marchetti 2009. In Powell's edition (1970), fr. 926(a) is labeled as a dithyramb and fr. $926(\mathrm{~g})$ as a partheneion.

62 See Grenfell 1898, 14; Blass 1899, 35. In the time of the New Music, there was continuity of themes between satyr-plays and dithyrambs (see on this LeVen 2014, 223).

63 See Klimek-Winter 1995, 93, 315-316 and Calvié 2014, 34-35, with bibliography on the hypothesis that fr. 926(g) belongs to Euripides' Andromeda. This fragment is part of some of the modern editions of Euripides' Andromeda (Bubel 1991 [fr. 4] and Jouan 1998, 188).

${ }^{64}$ LeVen 2014, 40.

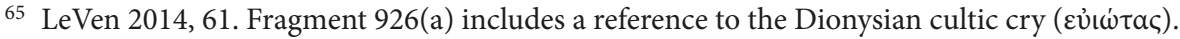

${ }^{66}$ LeVen 2014, 61-62.

${ }^{67}$ Page 1941, 395.

${ }^{68}$ Calame 1997, 43, n. 102. 
Both fragments have a great deal in common with partheneia. They were not intended for reading, provided that the author of the treatise has heard them performed. Both seem to be sung by a female chorus. However, their dating excludes the possibility that they belong to archaic partheneia. Thus, we are left to suggest that they are, in fact, partheneia that were composed during the time of the New Music. It is true that their mention of bacchantes and Dionysus situates them with dithyrambs. Still, it is not impossible for a poem to have generic affiliations with both dithyramb and partheneia at the same time due to the very nature of the latter.

Partheneia were sung by maiden choruses on religious occasions and marked the transition of their performers from adolescence to adulthood. Alcman, Pindar, and other poets are credited by the ancient tradition to have composed suchlike songs. ${ }^{69}$ They were also performed in classical Athens, ${ }^{70}$ although not a line survives of these oeuvres. The extant fragments have various and rather heterogeneous characteristics. Conceivably, partheneia is not a literary genre in the strict sense. ${ }^{71}$

Their authors, such as Alcman, and their audiences were conscious of composing songs to be performed by maidens on specific occasions. They were likewise aware of the distinctive character of the poems sung by these choruses. What the extant partheneia have in common is that they are related to the status of the performers. Hence a partheneion, at least until the Hellenistic times onward, could encompass even a dithyramb if performed by a maiden choir. ${ }^{72}$ We do encounter references to Dionysus in Alcman's fragments $\left(53,56\right.$ PMGF) that may belong to partheneia. ${ }^{73}$ The performance of a partheneion by bacchantes is not impossible. According to D'Alessio, there were Dionysian partheneia in classical Sparta. ${ }^{74}$ Considering vanishingly scarce evidence for dithyrambs performed by female choirs it is not impossible for a fragment to bear characteristics of a dithyramb and be classified under partheneia.

One of the most eminent characteristics of the fragments in question is their selfreferentiality, a well-known mark of partheneia: ${ }^{75} \beta \tilde{\alpha} \tau \varepsilon \beta \tilde{\alpha} \tau \varepsilon \kappa \varepsilon \tilde{\theta} \theta \varepsilon v$ in $926(\mathrm{~g})$ brings to mind other cases of the choral self-reference encountered in the opening lines of

${ }^{69}$ For ancient evidence on the genre see Hes. Theog. 205; Alcm. fr. 13 PMGF; Ar. Av. 919; Dion. Hal. Dem. 39; Suda s.v. $\pi \alpha \rho \theta \varepsilon v \varepsilon i \pi$; Phot. Bibl. 319b, 321a. Pindar's fragment 94 SM. probably belongs to this genre.

70 See Hamilton 1989; Swift 2010, 186-188; Almazova 2012, 63-70; Budelmann 2015.

71 Songs for the choruses of young women were composed and performed throughout the archaic and classical age. Aristophanes (Av. 919) uses the term partheneion showing that he is aware of the distinctive character of the poems sung by choruses of young women, without being more precise about the contents of partheneia. Nonetheless, it seems that the Alexandrians invented the technical term partheneion to classify a choral production that was otherwise difficult to classify. See on this Calame 1997, 88.

72 According to Calame, partheneia encompassed a variety of choral songs. In his study of the performances of women's choruses, he divides the songs the maidens sang into six categories (hymns, paeans, dithyrambs, citharodic nomoi, threnoi and epithalamia). See Calame 1997, 88.

${ }^{73}$ In fr. 53 PMGF, a female speaker (perhaps the maiden chorus) is dressed in animal skin. In fr. 56 PMGF, we encounter a description of a feast that takes place in the mountains. During this feast, the women are said to have produced cheese from a lion's milk for Hermes. Some of Alcman's partheneia might have had similar performative contexts (see on this Calame 1983b, 520-521 and the work of Bravo on female nocturnal dances).

74 See D’Alessio 2013.

75 For self-referentiality as a characteristic of the genre of partheneia see Pavese 1967, 133-134; Lefkowitz 1991, 23; Swift 2010, 175-185. For some of the self-referential moments of extant partheneia see, for example, Alcm. fr. 1, 64-76 PMGF, 3, 1-10 PMGF; Pind. fr. 94b, 6-15 SM. 
partheneia. ${ }^{76}$ The fragments describe the hic et nunc of the performance, as was usual in archaic partheneia. ${ }^{77}$ In fragment $926(\mathrm{~g})$, the speaker, who is probably a chorus of maidens, describes one girl (probably the chorus-leader) who seems detached from the rest of the maidens and gives them orders to take their positions to perform the song. ${ }^{78}$ It is the scenery, not the girls of the chorus, that is in the limelight in fr. 926(a). The performance seems to take place in an idyllic landscape that resembles other idyllic landscapes encountered in fragments of archaic lyric not belonging to partheneia but related to female singing activity. Sappho in fr. $2 \mathrm{~V}$ invokes Aphrodite to come from her temple in Crete, where there is a nice grove ( $\chi \alpha \dot{\alpha} \rho\llcorner\varepsilon v a ̈ \lambda \sigma o \varsigma)$ with apple trees. This place

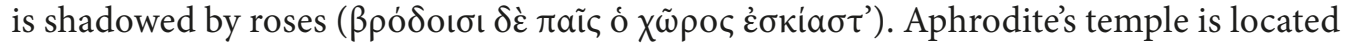

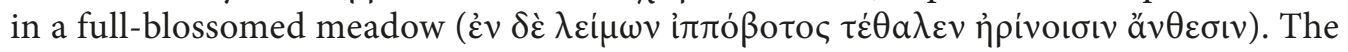
speaker uses the same marker for the invocation of a god ( $\left.\varepsilon^{\prime} v \theta \alpha \delta \dot{\eta}\right) .{ }^{79}$ The sensual tone is also the same. ${ }^{80}$ In Ibycus $286 P M G$, there is a description of an "unravished garden

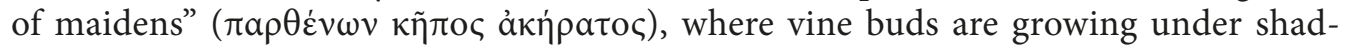
owy branches. ${ }^{81}$ Full-blossomed meadows, where maidens'Bacchic dances take place, also appear in Alcman's fr. 56 PMGF which is tied to a Dionysian context. In fr. 56 we encounter the description of a feast that occurs in a secluded place in the mountains. Fr. 926(a) might come from the beginning of a poem in which the landscape is amply described before a god is invoked - as in Sappho's $2 \mathrm{~V}$. The mention of immortal meadows seems more than natural in a cultic song by girls who may be speaking of maenads or even imitating them. ${ }^{82}$ They come together to participate in a choral performance. There is no mentioning of the deity they are going to honor. ${ }^{83}$ Nonetheless, both fragments 916(a) and (g) might belong to a cultic context, either real or imaginary. The phenomenon of choral projection, as it is observed in archaic partheneia, seems to occur, at least, in 926(g), if not in 926(a) also. The members of the chorus refer to their present or

76 See for example: Alcm. 3, 1-10 PMGF and Pind. 94b, 1-15 S-M.

77 The maidens in archaic partheneia refer to the ritual objects they carry during the ceremony (e. g., ФAPO $\Sigma$ in Alcman's fr. 1 PMGF and an unknown silver object that maybe was an offer to the gods in fr. 3, 77). They mention the musical instruments used in the performance of the song (cithara in Alcman's fr. 38; $\mu \alpha \dot{\gamma} \alpha \delta \mathrm{sc}$ in fr. 101; aulos in fr. 126). The maiden chorus also describes the place (possibly in lines 8 and 73 of

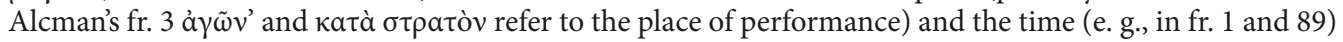
of the choral performance.

${ }^{78}$ For the eminent position of the chorus-leader in Alcman's partheneia see for example fr. 1, 44-59, 77, 96-98 PMGF. In Pindar's partheneia the chorus-leader is also the object of praise fr. 94b, 10-11, 6677 S-M. See Calame 1997, 59-62.

79 Dickmann-Boedeker 1974, 85; Stehle 1977, 98 n. 25.

80 Stehle 1977, 98, n. 25; McIntosh-Snyder 1991, 7-8.

81 This fragment has a lot in common with Sappho's poetry. See Bowra 1961, 244; Stehle 1977, 98, n. 35, with more bibliography. In Ibycus, nevertheless, there is no invocation of a god. The poet contrasts his desire and inner turmoil with the tranquility of nature. Mace 1996, 237, n. 24 has also noticed the similarities between fragment 926(a) and Ibycus' 286 PMG.

82 Diodorus Siculus described the worship of Dionysus in a similar setting. Choruses of maidens carry the thyrsus, feel the inspiration of the god and cry "Euai" while worshipping Dionysus (see Diodorus Siculus $4,3,3)$. Chryssoulaki provides an overview of the various Dionysiac festivals and rituals in which women participated. See Chryssoulaki 2008, 267-275.

${ }_{83}$ Grenfell and Hunt suggested that veãvıı could have been used to describe the epiphany of Dionysus $($ Grenfell 1898,20$)$. This seems unlikely, not only due to the female article, but because this was not a very usual cultic epithet of Dionysus. 
future activity, i. e., performing a song. ${ }^{84}$ The deixis enhances the self-referentiality and, as a result, the vividness of a poem. ${ }^{85}$

\section{5. "Reactionary" Songs?}

The fragments 916(a) and (g) can be considered late classical partheneia. Composed, as it seems, for female choruses, they are tied to the time of the New Music by a number of morphological features. The excerpt from the metrical treatise in which they are contained, must be of the same date. They have generic affiliations with dithyrambs and their diction seems to bear similarities to the language of drama. As Csapo has suggested, late classical cultic songs were influenced by drama. ${ }^{86}$ Supposedly, the songs from which these fragments come, have been composed with regard to cultic practices. This becomes more evident if we situate them with the rest of the fragments collected under 926 PMG. Less probable is that they imitate such songs within an unspecified dramatic context. Their differences from New Musical songs suggest that they belong to a different poetic school from that described by ancient literary criticism.

New Music was hardly considered revolutionary or radical beginning from the $4^{\text {th }}$ century BC. ${ }^{87}$ Its texts turned to be canonical, and their "programmatic principles" became the norm. Aristoxenus ${ }^{88}$ is the only source of a list of musicians and composers of the fourth century who worked outside the tradition of the New Music preserving the

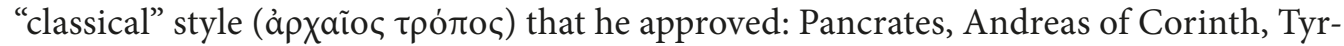
taeus of Mantinea, and Thrasylus of Phlius are praised for the archaic simplicity of the "classical" poets. Power notes that Aristoxenus' passage seems to indicate the existence of a dedicated school or movement of reactionary poets who emulated archaic lyric poetry. ${ }^{89}$ The dating of fragments $926(\mathrm{a})$ and $926(\mathrm{~g})$, which makes them contemporary with New Music, their discrepancy with "canonical" New Musical texts on the one hand, and their affinities with archaic epic and lyric poetry (especially with Alcman's partheneia) on the other allow us to assume that these fragments may give us a glimpse of an alternative poetic production composed alongside the New Music. They looked backward to the archaic and early classical tradition of partheneia, and their existence is, I think, an indication that, during the time of the New Music, there was a poetic tradition upheld by "reactionary" poets.

${ }^{84}$ Some of the examples of choral projection used in archaic partheneia are the following: Alcm. 3, 1-10 PMGF; Pind. 94b SM, 1-15.

85 Alcmanian partheneia (and to a certain degree Pindaric partheneia) were constructed to draw the attention of the audience to the ceremony and the maidens. Some of the markers of deixis encountered in

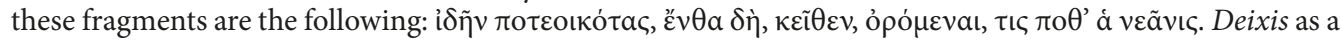

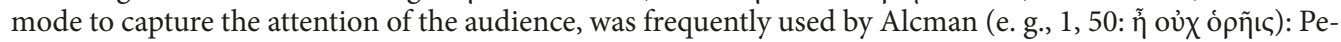
poni 2004, 295-316. Partheneia appeal especially to the sense of sight and they are rich in feminine imagery.

86 See Csapo 2004, 208.

87 See Power 2012, 129-130; LeVen 2014, 50-51. The stance of an aristocrat in Xenophon's Memorabilia who equates Melanippides to Homer, Sophocles, Polycleitus, and Zeuxis in their respective art and genre is indicative (see Xen. Mem. 1.4.3).

88 See [Plut.] De Mus. 1137e-1138c.

89 Power calls them the "Neoclassicists" (see Power 2012, 142). These poets opposed themselves to the mainstream. According to him, they were also those who tried their strength in the style of the New Dithyramb and archaic lyric poetry. 


\section{References}

Acosta-Hughes B. The Prefigured Muse, Rethinking a Few Assumptions on Hellenistic Poetics, in: J. J. Clauss, M. Cuypers (eds). A Companion to Hellenistic Literature, Oxford, Oxford University Press, 2010, 81-91.

Almazova N. A. Lyre on the Ground. Hyperboreus 2012, 16 (1), 54-74.

Blass F.W. Neuestes aus Oxyrhynchos (Aristoxenos, Alkman (?), Sappho). Neue Jahrbücher für das Klassische Altertum, Geschichte und Deutsche Literatur 1899, 2 (3), 30-49.

Bowra C. M. Greek Lyric Poetry from Alcman to Simonides. Oxford, Clarendon Press, 1961.

Bravo B. Pannychis e Simposio: Feste Private Notturne di Donne e Uomini nei Testi Letterari e nel Culto, con uno Studio Iconografico di Françoise Frontisi-Ducroux. Pisa - Roma, Istituti Editoriali e Poligrafici Internazionali, 1997.

Bubel F. (ed., comm.). Euripides. Andromeda, Stuttgart, Steiner, 1991.

Budelman F., LeVen P. A. Timotheus' Poetics of Blending: A Cognitive Approach to the Language of the New Music. CPh 2014, 109 (3), 191-210.

Budelmann F., Power T. Another Look at Female Choruses in Classical Athens. Cl. Ant. 2015, 34 (2), 252-295.

Calame C. Les Choeurs de Jeunes Filles II: Alcman. Roma, Edizioni dell'Ateneo e Bizzarri, 1983a.

Calame C. (ed., comm.). Alcman, Texte Critique, Témoignages, Traduction et Commentaire. Roma, Edizioni dell'Ateneo, 1983b.

Calame C. Choruses of Young Women in Ancient Greece: their Morphology, Religious Role, and Social Functions. Lanham, MD - New York - London, Rowman and Littlefield Publishers, 1997.

Calvié L. Le Fragment Rythmique du P. Oxy. 9+2687 Attribué à Aristoxène de Tarente. Revue de Philologie 2014, 88 (1), 7-54.

Campbell D. A. (ed., comm.). Greek Lyric, Volume V: The New School of Poetry and Anonymous Songs and Hymns. Cambridge, MA — London, Harvard University Press, 1993.

Chryssoulaki S. The Participation of Women in the Worship and Festivals of Dionysos, in: N.Kaltsas, A. Shapiro (eds) Worshiping Women. Ritual and Reality in Classical Athens. Athens - New York, 2008, Alexander S. Onassis, 267-275.

Cole T. Epiploke: Rhythmical Continuity and Poetic Structure in Greek Lyric. Cambridge, MA, Harvard University Press, 1988.

Csapo E. Later Euripidean Music. ICS 1999-2000, 24-25, 399-426.

Csapo E. The Dolphins of Dionysus, in: E. Csapo, M. Miller (eds) Poetry, Theory, Praxis: The Social Life of Myth, Word and Image in Ancient Greece. Essays in Honor of William J. Slater. Oxford, Oxbow, 2003, $68-98$.

Csapo E. The Politics of the New Music, in: P. Murray, P. Wilson (eds) Music and the Muses: The Culture of Mousike in the Classical Athenian City. Oxford, Oxford University Press, 2004, 207-248.

Csapo E. New Music's Gallery of Images: the "Dithyrambic" First Stasimon of Euripides' Electra, in: J. R. C. Cousland, J. R. Hume (eds) The Play of Texts and Fragments: Essays in Honour of Martin Cropp. Leiden, Brill, 2009, 91-109.

Csapo E. The Economics, Poetics, Politics, Metaphysics, and Ethics of the "New Music", in: D. Yatromanolakis (ed.) Music and Cultural Politics in Greek and Chinese Societies: Volume 1: Greek Antiquity. Cambridge, MA, Harvard University Press, 2011, 65-135.

Dale A. M. The Lyric Metres of Greek Drama. Cambridge, Cambridge University Press, 1948.

D'Alessio G. B. The Name of the Dithyramb: Diachronic and Diatopic Variations, in: B. Kowalzig, P. Wilson (eds) Dithyramb in Context. Oxford, Oxford University Press, 2013, 113-132.

D’Angour A. The New Music: So What's New, in: S. Goldhill, R. Osborne (eds) Rethinking Revolution through Ancient Greece. Cambridge, Cambridge University Press, 2006, 264-283.

Denniston J. D. Lyric Iambics in Greek Drama, in: Greek Poetry and Life, Essays Presented to Gilbert Murray. Oxford, Clarendon Press, 1936, 121-144.

Dickmann-Boedeker D. Aphrodite's Entry into Greek Poetry. Leiden, Brill, 1974.

Dover K. J. Ancient Greek Literature. Oxford, Oxford University Press 1997.

Fearn D. Lyric Reception and Sophistic Literality in Timotheus' Persae, in: B. G. F. Currie, I. Rutherford (eds) The Reception of Greek Lyric Poetry 600 BC-400 AD: Transmission, Canonization, and Paratext. Proceedings of the Network for the Study of Archaic and Classical Greek Song. Leiden, Brill, 2015, 1-39. 
Ford A. The Origins of Criticism: Literary Culture and Poetic Theory in Classical Greece. Princeton, Princeton University Press, 2002.

Ford A. The Poetics of Dithyramb, in: P. Wilson, B. Kowalzig (eds) Dithyramb in Context. Oxford, Oxford University Press, 2013, 313-331.

Franklin J.C. Song-benders of Circular Choruses. Dithyramb and the Demise of Music, in: P.Wilson, B. Kowalzig (eds) Dithyramb in Context. Oxford, Oxford University Press, 2013, 213-236.

Gentili B., Lomiento L. Problemi di Ritmica Greca, in: B. Gentili, F. Perusino (eds) Mousike. Metrica, Ritmica e Musica Greca in Memoria di Giovanni Comotti. Pisa - Roma, Istituti Editoriali e Poligrafici Internationali, 1995, 61-76.

Grenfell B., Hunt A. The Oxyrhynchus Papyri I. London, Egypt Exploration Society, 1898.

Jouan F., Van Looy H. (ed., comm.). Euripide, Tragédies. Tome viii. Paris, CUF, 1998.

Hamilton R. Alcman and the Athenian Arkteia. Hesperia 1989, 58 (4), 449-472.

Henrichs A. "Why should I Dance?": Choral Self-Referentiality in Greek Tragedy. Arion 1994-1995, 3 (1), 56-111.

Henrichs A. Dancing in Athens, Dancing on Delos: Some Patterns of Choral Projection in Euripides. Philologus 1996, 140, 48-62.

Hordern J.H. (ed., comm.). The Fragments of Timotheus of Miletus. Oxford, Oxford University Press 2002.

Irigoin J. Euripide Poète et Musicien selon Denys d'Halicarnasse. Pallas 2006, 72, 219-227.

Klimek-Winter R. Andromedatragödien. Sophokles, Euripides, Livius Andronikos, Ennius, Accius. Text, Einleitung und Kommentar. Stuttgart, B. G. Teubner, 1993.

Koster W.J. Quelques Remarques sur l'Etude Rhythmique [de l'Ecole d'Aristoxene]: Ox. Pap. 2687. REG $1972,85,47-56$.

Lefkowitz M. R. First-Person Fictions, Pindar's Poetic I. Oxford, Oxford University Press, 1991.

LeVen P.A. New Music and its Myths: Athenaeus' Reading of the Aulos Revolution 'Deipnosophistae 14.616e-617f'. JHS 2010, 130, 35-47.

LeVen P. A. The Many-Headed Muse: Tradition and Innovation in Late Classical Greek Lyric Poetry. Cambridge - New York, Cambridge University Press, 2014.

Mace S. Utopian and Erotic Fusion in a New Elegy by Simonides (22 West). ZPE 1996, 113, 233-247.

Marchetti C. C. Aristoxenus' Elements of Rhythm: Text, Translation, and Commentary with a Translation and Commentary on POXY 2687. New Jersey, Diss. Rutgers, 2009.

Martin R. The Pipes Are Brawling: Conceptualizing Musical Performance in Athens, in: C.Dougherty, L. Kurke (eds) The Cultures within Ancient Greek Culture: Contact, Conflict, Collaboration. Cambridge, Cambridge University Press, 2003, 153-180.

Mathiesen T.J. Apollo's Lyre: Greek Music and Music Theory in Antiquity and the Middle Ages. Nebraska, University of Nebraska Press, 1999.

McIntosh-Snyder J. Public Occasion and Private Passion in the Lyrics of Sappho, in: S. B. Pomeroy (ed.) Women's History and Ancient History. Chapel Hill, London, UNC Press Books, 1991, 1-19.

Mülke C. Solons Politische Elegien und Iamben (Fr. 1-13; 32-37 West). Einleitung, Text, Übersetzung, Kommentar. München - Leipzig, K. G. Saur, 2002.

Nagy G. Pindar's Homer: The Lyric Possession of an Epic Past. Baltimore - London, Johns Hopkins University Press, 1990.

Nagy G. The Delian Maidens and their Relevance to Choral Mimesis in Classical Drama, in: R. Gagné, M. G. Hopman (eds) Choral Mediations in Greek Tragedy. Cambridge, Cambridge University Press, 2013, 227-256.

Neer T., Kurke L. Pindar Fr. 75 SM and the Politics of Athenian Space. GRBS 2014, 54, 527-579.

Nooter S. The Mortal Voice in the Tragedies of Aeschylus, Cambridge, Cambridge University Press, 2017.

Page D. L. (ed., comm.). Select Papyri III. London - Cambridge, MA, Loeb Classical Library, 1941.

Page D. L. (ed., comm.). Poetae Melici Graeci. Oxford, Oxbow Books, 1962.

Pearson L. (ed., comm.). Aristoxenus Elementa Rhythmica: The Fragments of Book II and the Additional Evidence for Aristoxenean Rhythmic Theory. Oxford, Clarendon Press, 1990.

Pavese C. O. Alcmane, il Partenio del Louvre. QUCC, 1967, 4, 113-133.

Peponi A.E. Initiating the Viewer: Deixis and Visual Perception in Alcman's Lyric Drama. Arethusa 2004, 37, 295-316.

Powell J. U. (ed., comm.). Collectanea Alexandrina, Reliquae Minoris Poetarum Graecorum Aetatis Ptolemaice 323-146 A. C. Oxford, Clarendon Press, 1970.

Power T. The Culture of Kitharôidia. Washington, Center for Hellenic Studies, 2010. 
Power T. Aristoxenus and the "Neoclassicists", in: C. A. Huffmann (ed.) Aristoxenus of Tarentum: Discussion. New Brunswick, NJ, Transaction Publishers, 2012, 129-154.

Power T. Kyklops Kitharoidos: Dithyramb and Nomos in Play, in: P. Wilson, B. Kowalzig (eds) Dithyramb in Context. Oxford, Oxford University Press, 2013, 237-256.

Reinach T. Sur une Nouvelle Papire Musicale. REG 1898, 11, 398-415.

Reiter S. De Syllabarum in Trisemam Longitudinem Productarum uso Aeschyleo et Sophocleo. PhD. Diss., Universität Wien, 1887.

Reiter S. Drei- und Vierzeitige Längen bei Euripides. SBAW 1893, 129.

Rossi L. E. POxy 9+ POxy 2687: Trattato Ritmico-Metrico, in: A. Brancacci (ed.) Aristoxenica, Menandrea Fragmenta Philosophica. Studi e Testi per il Corpus dei Papiri Filosofici Greci e Latini. Firenze, Olschki, 1988, 11-30.

Schönewolf H. Der Jungattische Dithyrambos, Wesen, Wirkung, Gegenwirkung. Diss. Gießen, 1938.

Seaford R. Euripides: Bacchae, with an Introduction, Translation and Commentary. Warminster, Aris \& Phillips, 1996.

Stanford B. The Sound of Greek: Studies in the Greek Theory and Practice of Euphony. Berkeley, University of California Press, 1967.

Stehle-Stigers E. Retreat from the Male: Catullus 62 and Sappho's Erotic Flowers. Ramus 1977, 6 (2), 83-102.

Swift L. A. The Hidden Chorus: Echoes of Genre in Tragic Lyric. Oxford - New York, Oxford University Press, 2010.

Weiss N. The Music of Tragedy: Performance and Imagination in Euripidean Theater. Oakland, University of California Press, 2018.

West M.L. Greek Metre. Oxford, Oxford University Press, 1982.

West M.L. Studies in Aeschylus. Stuttgart, De Gruyter, 1990.

Wilamowitz-Moellendorff U. (rec.) B. Grenfell, A. Hunt. The Oxyrhynchus Papyri. I. London, 1898. Göttingische Gelehrte Anzeigen 1898, 160, 673-704. 